\title{
GIS-based land suitability assessment for Musa (ABB group) plantation
}

\author{
Jaruntorn Boonyanuphap, Det Wattanachaiyingcharoen and Katsutoshi Sakurai
}

Graduate School of Agricultural Science, Ehime University, Matsuyama, 790-8566, Japan.

\begin{abstract}
Bananas and plantains are the developing world's fourth most important food commodity but supply could exceed demand by the end of the decade. An effective method of assessing environmental suitability for the extending banana plantation is needed. A multifactor spatial analysis can effectively assess the environmental suitability of an area for use as a banana plantation. This approach used the Geographic Information System (GIS), a combination of five environmental factors consisting of nineteen variables to express land suitability in five classes. One site was chosen for site assessment. This site fell in to a range of categories from highly suitable (S1) to not suitable (N1). To supply future demand for dried banana products information has to be integrated from land use types, current environmental conditions, soil characteristics, and the possibility for adjusting environmental conditions to make them more suitable for future growth. All of these factors were used to determine possible areas for new banana plantations under land management practices in Thailand.
\end{abstract}

Key words: Musa (ABB group), Geographic Information System (GIS), land suitability

\section{Introduction}

The Consultative Group on International Agriculture Research (CGIAR) reported that bananas and plantains are the developing world's fourth most important food commodity after rice, wheat and maize (Wattanachaiyingcharoen and Boonyanuphap, 2003). They are the major staple food for many millions of people throughout the tropical countries and provide a valued source of income through local and international trade. However, the importance of the crop has been largely overlooked and until the 1980s, very little research was done to improve it (INIBAP, 2001). According to the FAO report, under existing production and trade conditions, banana supplies could exceed demand by the end of the decade. FAO projections show global banana exports, put at 12.87 million tons in 1999, and import demand of 12.22 million tons, resulting in a 650,000 ton surplus. Approximately $82 \%$ of banana consumption in Thailand is Musa (ABB group) 'Kluai Nam Wa'. The trend of banana consumption in Thailand has been increasing because Musa (ABB group) can be industrially processed into various kinds of product. Moreover, the current development of preserved banana products is contributing to household industry for small-scale farmer (Wattanachaiyingcharoen, 2002).

The Bang Kratum district, Phitsanulok province, Thailand, had a large area of banana plantations in the past. This area had been producing many kinds of preserved banana products. The dried banana product had especially been the most famous gift for tourists. The process of dried banana production needs 20 tons per day of ripened banana. Wattanachaiyingcharoen (2002) reported that the requirement of using ripened banana for dried banana production at Bang Kratum community is more than 6,000 ton per year. However, this area can not supply that large demand of ripened banana due to the small area of banana plantation.

In this current situation, the community has to carry bananas from other distant areas such as Uttaradit, Sukhothai, and Phichit provinces due to the change of original banana plantation areas into other land use types. Because of Fusarium wilt (Panama disease of banana), most banana plantation areas have degrading land resources for banana plantations which increase cost of production. It is necessary to assess the land suitability for banana plantation in the area by integrating various kinds of information with spatial analysis technique. The result of land suitability assessment presented in the form of map and report are meaningful to a local user. Geographic Information System can be effectively applied to handle such kinds of work and to complete study objectives, these are (1) to construct the geographical databases of land suitability for Musa (ABB group) plantation, (2) to assess land suitability for Musa (ABB group) using Geographic Information System, and (3) to select the possible lands for new banana plantation.

\section{Materials and methods}

Study site description: The study was carried out in Bang Kratum district, Phitsanulok province, Lower Northern Thailand, which is one of the original and famous area for dried banana production; however, the reduction of planting area has occurred due to Fusarium wilt and degradation of land resources. The study area covers approximately 34,866 hectares or $3.45 \%$ of total area of Phitsanulok province (Fig. 1). It is geographically located between the $16^{\circ} 31^{\prime}-16^{\circ} 44^{\prime}$ of north latitude and $100^{\circ} 14^{\prime}-100^{\circ} 32^{\prime}$ of east longitude.

The area mostly has a mean annual rainfall between 1,000 and $2,000 \mathrm{~mm}$ and a mean annual rain day ranging from 38 to 135 days. The average annual temperature and drought period a year is between 25 and $28^{\circ} \mathrm{C}$ and between 3 and 4 months, respectively. The topography consists of only a flat low land with slopes less than $2 \%$ with an altitude ranging from 35 to $55 \mathrm{~m}$ above mean sea level. The bedrock is stratified with sedimentary rock, 
Quaternary (Cenozoic) era. The west of the site reveals a natural gravely alluvial deposit, while the terrace deposit appears in the east. This area is dominated with broadcasted paddy field and lowland filed with the area of mixed orchard, approximately 17.80 $\%$ of the study area. Locations of the local markets are only in three subdistricts, in the central part of study site, namely Nakon Pamak, Bang Krathum, and Phai Lom subdistricts.

The soil in the study area includes twenty seven soil series, which are grouped into thirteen soil groups by the Land Development Department (1998). The study area shows various soil properties. Among them, the clayey soil is dominant $(72.79 \%$ of the total area) and is highly suitable for paddy field. The soil properties are mostly slightly acidic with $\mathrm{pH}$ ranging from 4.5 to 7.5 with poor drainage. CEC of the soils ranged from 5.01 to $35.3 \mathrm{cmol}$ $(+) \mathrm{kg}^{-1}$ and total $\mathrm{C}$ of soils varies between 0.96 and $4.27 \%$. Supplementary surface water sources for agricultural use is moderately well supplied in the west and central part of study area. Additionally, this area has a good transportation network.

Study method: This investigation was part of a study on the production management of Musa (ABB group) for export and agro-industry using Geographic Information System (GIS) in Bang Kratum district, Phitsanulok province, Lower Northern Thailand (Wattanachaiyingcharoen and Boonyanuphap, 2003). GIS was used to build the geographic database for banana plantations as well as for land suitability assessment for banana plantations using multifactor spatial analysis. Using Global Positioning System (GPS) during field survey in November 2002 collected the locations of household factories. The general flow of the study procedure is shown in Fig. 2.

Data collection and geographic database construction: The field data and secondary data of the relative factors and variables in banana plantation were collected on climate, topography, soil, land use type and economic condition in the study area. The

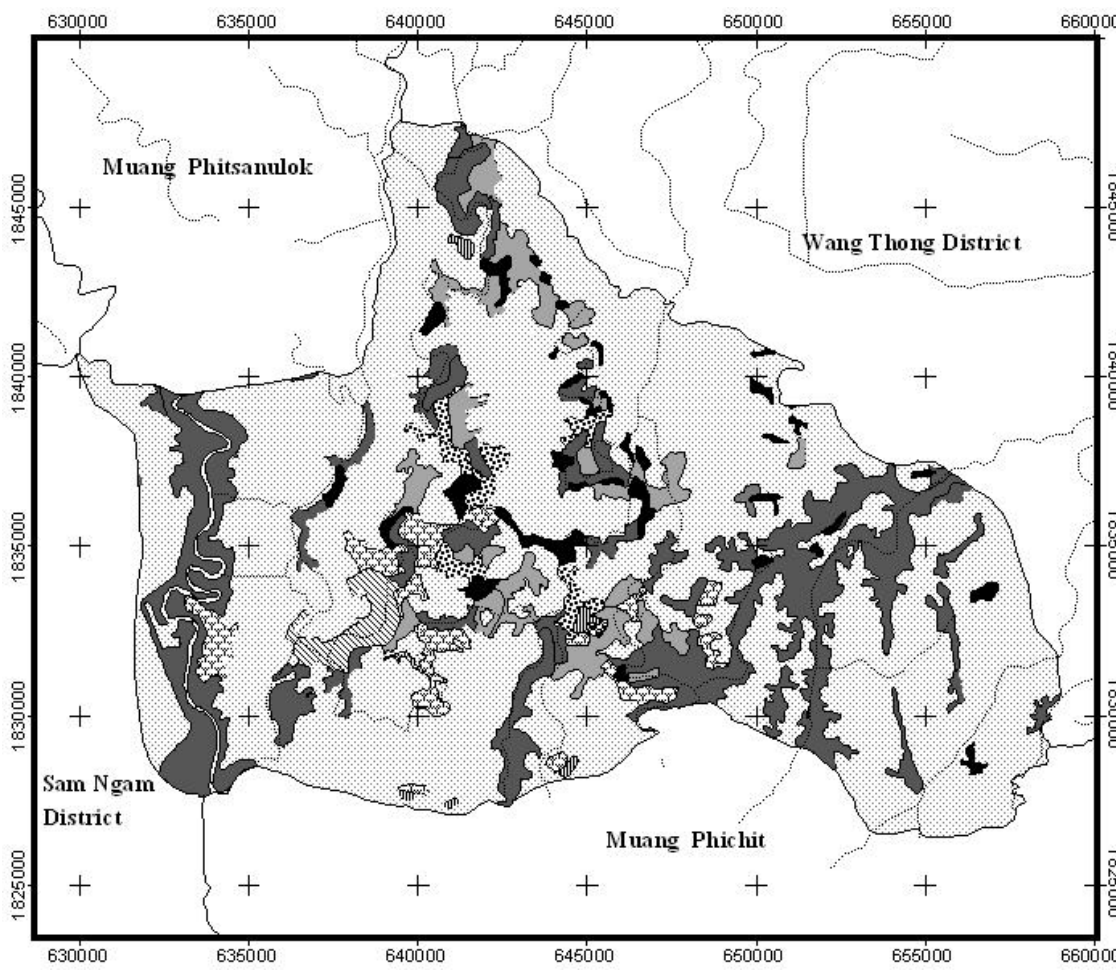

Fig. 1. Location of the study site, Bang Kratum district and land use type in year 2002 information was used to construct geographical databases using GIS approaches. The selected nineteen variables have been grouped into five environmental factors on the basis of their specific relationship with the assessment of land suitability for banana plantation, namely (1) soil property, (2) topographic, (3) climatic, (4) supplementary water, and (5) marketing factor. These five environmental factors were basically different in their dependence on land suitability.

Determination of the weight of factors and variables: The weight of factors and variables were determined depending on the importance of each variable in comparison with the others in the same factor group as well as between environmental factors (Table 1 and 2). The more important the factor and variable, the higher the weight. The weight and scores were mostly based Hackett and Carolane (1982), Griffiths (1994) and discussion with regional officers (Table 3 ).

Table 1. Weight and score of the environmental suitability for Musa (ABB group) plantation

\begin{tabular}{llll}
\hline Weight & Importance & Score & Suitable level \\
\hline 1 & very low & 2 & currently not \\
suitable & & & \\
2 & low & 4 & marginally suitable \\
3 & medium & 6 & moderately suitable \\
4 & high & 8 & highly suitable \\
\hline
\end{tabular}

Classification on the current environmental suitability: Study on spatial distribution pattern in each variable provided information about current environmental situation in both geographical and economic aspects. All scored variables, which restored in vector-based geodatabases, were converted into the raster-based datasets with 20-meter grid cell size, because the raster-based overlay analysis has more advantage in the map algebra technique.
Legend<smiles></smiles>

Land use in year 2002

Paddy field

City, town, commercial and service 登涪Factory

Residential land/ low land village

M. Mixed field crop/mixed perennials

Mixed orchard

Sugarcane

Wetland

River/ reservoir /lake

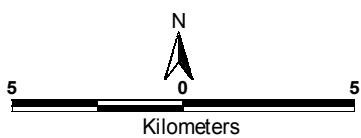




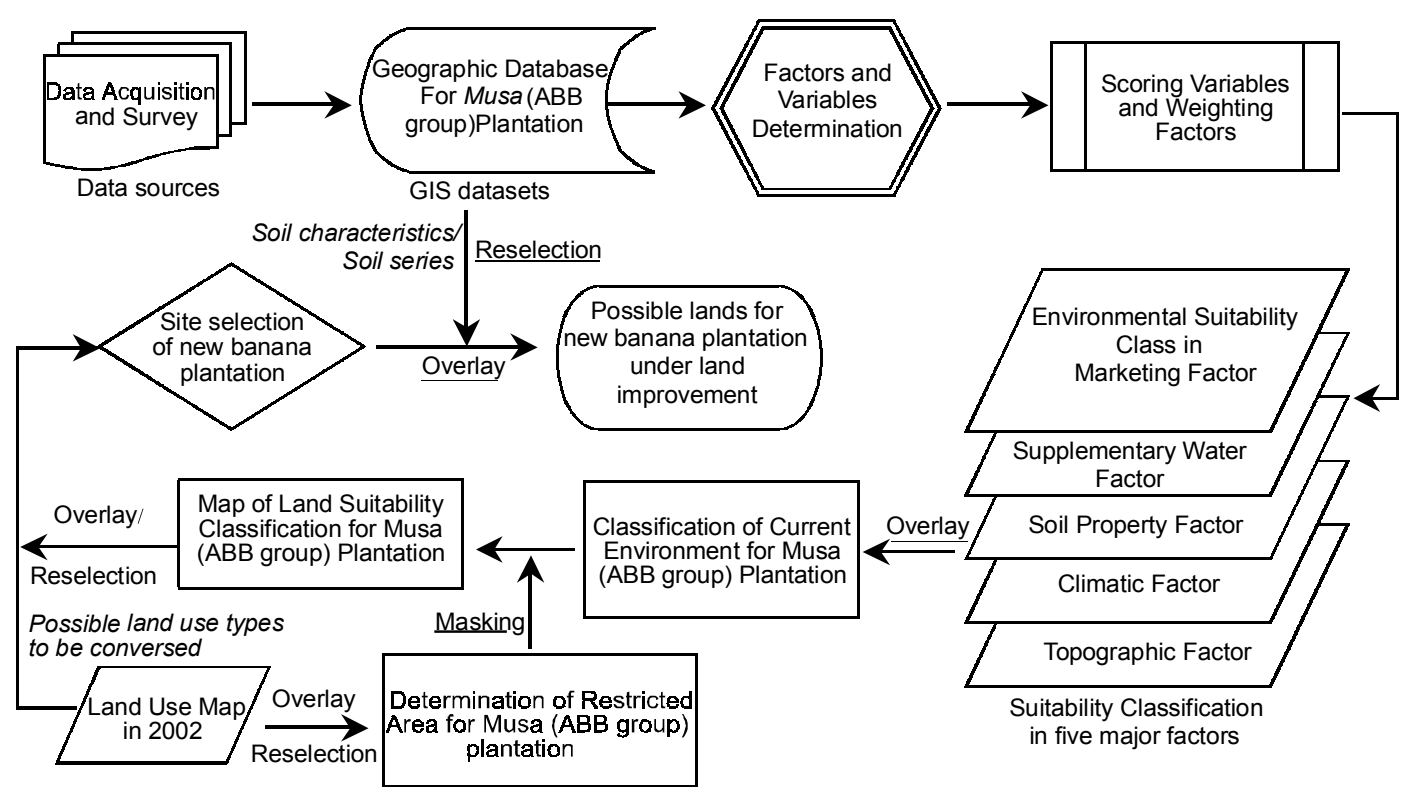

Fig. 2. General flow of study procedure

The variables in each environmental factor were overlaid together to build five new datasets on current environmental suitability for each environmental factor. The grid cells in each dataset contained the suitable value of the current environment for banana plantation, with the higher value, the more suitable. Each factor on current environmental suitability was reclassified into 4 levels of suitability using the equal interval range technique. These were, currently not suitable (N1), marginally (S3), moderately (S2), and highly suitable (S1) as well as assigned the value of each suitable level as $2,4,6$, and 8 , respectively.

To classify the current environmental suitability of the study site, all five reclassified current environmental suitability factors were

Table 2. Weight variable and factor for Musa (ABB group) plantation

\begin{tabular}{lclc}
\hline Main Factor & Weight & Variable & Weight \\
\hline Marketing Factor & 4 & Distance from factory & 4 \\
& & Distance from main road & 3 \\
Climatic Factor & 3 & Mean annual rainfall & 4 \\
& & Mean annual rain day & 4 \\
& & Drought Period & 4 \\
Supplementary & 3 & Mean annual temperature & 3 \\
Water Factor & & Distance from permanent stream & 4 \\
& & Distance from surface water area & 4 \\
& & Distance from irrigation zone & 4 \\
& & Aquifer Rock Type & 3 \\
& & (ground water quantity) & \\
& & Distance from well & 3
\end{tabular}

Soil Property 2

Factor

\begin{tabular}{|c|c|c|}
\hline & Soil texture & 3 \\
\hline & Soil depth & 3 \\
\hline & Soil drainage & 4 \\
\hline & Soil pH & 4 \\
\hline & Soil CEC & 4 \\
\hline & Total C & 4 \\
\hline Topographic & 1 & \\
\hline \multirow{2}{*}{ Factor } & Slope & 4 \\
\hline & Elevation & 3 \\
\hline
\end{tabular}

weighted (Table 2) and then overlaid together using the add overlay operation. This procedure created new datasets of the overall current environmental suitability for banana plantation based on all environmental factors. This new dataset was finally reclassified into 4 classes of current environmental suitability in the study site.

Determination of the restricted areas from use as banana plantation: The land use dataset in year 2002 was used to determine the restricted area from use as banana plantation. The selected areas of city and commercial zone, urban area, industrial land, and water bodies were classified as permanently not suitable area for banana plantation (N2). These restricted areas were recoded as zero to avoid assessing the land suitability for banana plantation.

Assessment of land suitability for banana plantation: The restricted area was overlaid with the reclassed current environmental suitability datasets using the multiple overlay operation to assess land suitability for banana plantation.

Matching of exiting land use and soil characteristics with land suitability classes presented possible lands for new banana plantation. Land use map in year 2002 and soil characteristics information were combined with the map of land suitability class, which was used to select a possible lands for banana plantation. Within the areas of all suitable class (S1, S2 and S3), the lands for abandoned paddy field, mixed orchard, and mixed orchard with low land village were selected as possible lands, which were able to be changed into banana plantations. Additionally, the areas of preferable soil characteristics for banana plantation under specific land improvements were also selected to estimate the total land for supplying the demand on dried banana plantation in the study area.

\section{Results and discussion}

Classification of the current environmental suitability: Considering current environmental conditions, it is essential to use information for physical assessment of land suitability at first. This kind of information provides the overall current condition 
Table 3. Score of each variable category (Hackett and Carolane, 1982; Griffiths, 1994; Asian Institute of Technology, 2001)

\begin{tabular}{|c|c|c|c|c|c|}
\hline Variable & Category & Score & Variable & Category & Score \\
\hline Soil & heavy clay & 2 & Mean Annual & $<10$ or $>35$ & 2 \\
\hline \multirow[t]{3}{*}{ Texture ${ }^{\#}$} & sic, $c$ & 4 & Temperature & $10-20$ or $30-35$ & 4 \\
\hline & sc & 6 & (Degree & $20-25$ or $28-30$ & 6 \\
\hline & s, Is, sl, l, sil, scl, cl, sicl & 8 & Celsius) & $25-28$ & 8 \\
\hline Soil Depth & $<30$ & 2 & Drought & $>4$ & 2 \\
\hline \multirow[t]{3}{*}{ (Centimeter) } & $30-50$ & 4 & (Month) & $3-4$ & 4 \\
\hline & $50-80$ & 6 & & $1-3$ & 6 \\
\hline & $>80$ & 8 & & $<1$ & 8 \\
\hline Soil & Very poor or very excessive & 2 & Distance from & $>1,500$ & 2 \\
\hline \multirow[t]{3}{*}{ Drainage } & Poor or somewhat excessive & 4 & Stream & $1,000-1,500$ & 4 \\
\hline & Somewhat poor or excessive & 6 & Network & $500-1,000$ & 6 \\
\hline & Well or Moderate well & 8 & (Meter) & $<500$ & 8 \\
\hline \multirow[t]{4}{*}{ Soil pH } & $<4.5$ or $>8.5$ & 2 & Distance from & $>1,500$ & 2 \\
\hline & $4.5-5.4$ or $7.6-8.5$ & 4 & Surface Water & $1,000-1,500$ & 4 \\
\hline & $5.5-5.9$ or $7.1-7.5$ & 6 & Source & $500-1,000$ & 6 \\
\hline & $6.0-7.0$ & 8 & (Meter) & $<500$ & 8 \\
\hline Soil CEC & $<5$ & 2 & Distance from & $>5$ & 2 \\
\hline$(\mathrm{cmol}(+)$ & $5-15$ & 4 & Irrigation Zone & $1-5$ & 4 \\
\hline \multirow[t]{2}{*}{$\left.\mathrm{kg}^{-1}\right)$} & $15-25$ & 6 & (Kilometer) & $0-1$ & 6 \\
\hline & $>25$ & 8 & & Inside Irrigation zone & 8 \\
\hline Total C & $<1$ & 2 & Quantity of & $0-50$ & 2 \\
\hline \multirow[t]{3}{*}{$(\%)$} & $1-2$ & 4 & Ground water & $50-100$ & 4 \\
\hline & $2-3$ & 6 & (Gallon & $100-150$ & 6 \\
\hline & $>3$ & 8 & (Minute) & $>150$ & 8 \\
\hline Slope & $>35$ & 2 & Distance from & $>500$ & 2 \\
\hline \multirow[t]{3}{*}{$(\%)$} & $16-35$ & 4 & Location of & $300-500$ & 4 \\
\hline & $8-16$ & 6 & well & $100-300$ & 6 \\
\hline & $0-8$ & 8 & (Meter) & $<100$ & 8 \\
\hline Elevation & $0-1,800$ & 2 & Distance from & $>10$ & 2 \\
\hline \multirow[t]{3}{*}{ (Meter) } & $1,800-1,900$ & 4 & Factory & $5-10$ & 7 \\
\hline & $1,900-2,000$ & 6 & (Kilometer) & $1-5$ & 6 \\
\hline & $>2000$ & 8 & & $<1$ & 8 \\
\hline Mean & $0-700$ or $3,000-5,000$ & 2 & Distance from & $>10$ & 2 \\
\hline Annual & $700-1,000$ or $2,500-3,000$ & 4 & Road Network & $5-10$ & 4 \\
\hline Rainfall & $1,000-1,500$ or $2,000-2,500$ & 6 & (Kilometer) & $1-5$ & 6 \\
\hline (Millimeter) & $1,500-2,000$ & 8 & & $<1$ & 8 \\
\hline Mean & $0-50$ & 2 & & & \\
\hline Annual & $50-70$ & 4 & & & \\
\hline Rain day & $70-90$ & 6 & & & \\
\hline (Day) & $>90$ & 8 & & & \\
\hline
\end{tabular}

\#c, clay; sic, silty clay; sc, sandy clay ; s, sand; Is, loam sand ; sl, sandy loam; I, loam; sil, silt loam; scl, sandy clay loam ; cl, clay loam; sicl, silty clay loam

of land, which related to the requirement and limitation of the banana plantation based on the reviewed literatures. The current environmental suitability class in each factor was created from overlaying all variables within the factor. Table 4 shows the suitability class of current environment in five environmental factors. The current environmental suitability expresses the potential physical productivity of land as well as the possibility for land improvement. The entire study site had highly suitable class in terms of the topography factor while most of the study area fell in to marginally to moderately suitable classes considering the climatic factor. The study site was mostly classified as marginally and moderately suitable classes in both of the soil property and marketing factors.

According to the supplementary water factor, the study site had especially more currently not suitable area (N1) than the other factors. Consequently, the one irrigation project had been established for only small area coverage in the study site. To the soil property factor, the study site was mostly assessed into marginally to moderately suitable classes $(89.81 \%$ of the study site). In fact, some soils might be improved by prolonged application of fertilizer and manure. However, it is necessary to assess the cost of improvements. Economic analysis should be considered for studying the feasibility of land improvement.

The five current environmental suitability factors were together overlaid to create the current environmental suitability in the study area. The result presents that the overall current environmental condition in the study site, which is mostly classified as a moderately suitable class for banana plantation with $49.30 \%$ of the study area, while the highly suitable class is determined as the smallest area (Table 5). 
Table 4. Suitability class of current environment in the study area

\begin{tabular}{|c|c|c|c|c|c|c|c|c|c|c|}
\hline \multirow[t]{2}{*}{ Suitability Class } & \multicolumn{2}{|c|}{$\begin{array}{l}\text { Soil Property } \\
\text { Factor }\end{array}$} & \multicolumn{2}{|c|}{$\begin{array}{l}\text { Topography } \\
\text { Factor }\end{array}$} & \multicolumn{2}{|c|}{$\begin{array}{l}\text { Climatic } \\
\text { Factor }\end{array}$} & \multicolumn{2}{|c|}{$\begin{array}{l}\text { Supplementary } \\
\text { Water Factor }\end{array}$} & \multicolumn{2}{|c|}{$\begin{array}{l}\text { Marketing } \\
\text { Factor }\end{array}$} \\
\hline & $\overline{\text { Area (ha) }}$ & $\%$ & $\overline{\text { Area (ha) }}$ & $\%$ & $\overline{\text { Area (ha) }}$ & $\%$ & $\overline{\text { Area (ha) }}$ & $\%$ & Area (ha) & $\%$ \\
\hline Currently not suitable (N1) & $2,125.84$ & 6.10 & 0.00 & 0.00 & $2,270.32$ & 6.51 & $11,103.68$ & 31.85 & $5,308.00$ & $\overline{15.22}$ \\
\hline Marginally suitable (S3) & $15,341.76$ & 44.00 & 0.00 & 0.00 & $13,539.88$ & 38.83 & $10,165.68$ & 29.16 & $12,801.68$ & 36.72 \\
\hline Moderately suitable (S2) & $15,972.52$ & 45.81 & 0.00 & 0.00 & $10,139.36$ & 29.08 & $11,648.68$ & 33.41 & $13,551.44$ & 38.87 \\
\hline Highly suitable (S1) & $1,426.12$ & 4.09 & $34,866.24$ & 100.00 & $8,916.68$ & 25.57 & $1,948.20$ & 5.59 & $3,205.12$ & 9.19 \\
\hline Total & $34,866.24$ & 100.00 & $34,866.24$ & 100.00 & $34,866.24$ & 100.00 & $34,866.24$ & 100.00 & $34,866.24$ & 100.00 \\
\hline
\end{tabular}

Table 5. Ranging suitable score of current production for Musa (ABB group) plantation

\begin{tabular}{llcc}
\hline $\begin{array}{l}\text { Ranging of } \\
\text { Suitable Score }\end{array}$ & $\begin{array}{l}\text { Suitability } \\
\text { Class }\end{array}$ & Area (ha) & $\begin{array}{c}\text { \% of Total } \\
\text { Area }\end{array}$ \\
\hline $40-53$ & Currently not suitable (N1)5,488.40 & 15.74 \\
$54-67$ & Marginally suitable (S3) & $11,051.48$ & 31.70 \\
$68-80$ & Moderately suitable (S2) & $17,189.04$ & 49.30 \\
$81-94$ & Highly suitable (S1) & $1,137.32$ & 3.26 \\
Total & & $34,866.24$ & 100.00 \\
\hline
\end{tabular}

Determination of the restricted area from use for banana plantation: The restricted areas were derived from the digital land use map in year 2002 from the Land Development Department, Thailand (2002). According to the nine land use types in year 2002, it exhibited that some types of land had already been developed for permanent use or had less possiblity of change in the near future. In that case, these land use types were defined as the permanently not suitable class (N2), which consist of city and commercial area, residential area / low land village, industrial land, and water bodies. The restricted areas were mainly residential areas and low land villages with only small areas of industrial land. Total area of permanently not suitable area for banana plantation was approximately 1,629.12 hectare or 4.68 $\%$ of the study area.

Assessment of land suitability for banana plantation: The result of land suitability assessment showed that Bang Kartum district was mostly assessed as the moderately suitable class with area of $1,026.97$ hectare or $47.13 \%$ of the total area (Table 6). The land suitability map provided the most satisfactory means of conveying the result of assessment to the user in summary form (Fig. 3). The highly suitable areas for banana plantation were mainly located close to household factories and surface water sources. Soil characteristics of the highly suitable class were mostly clay and deep to very deep soil, with poor drainage and 2 or 3 months flood in the rainy season during September to November. Soils in the highly suitable class were also slightly acidic (pH 6 to 7 ) as well as moderate total C (2 to $3 \%$ ) and CEC (15 to $\left.25 \mathrm{cmol}(+) \mathrm{kg}^{-1}\right)$.

The southeast part of study site had mainly been classed as currently not suitable area (N1) because this region had low water sources for agricultural activity relating to the current condition in supplementary water factor. In this case, if irrigation is established in the region, the environmental effects in water

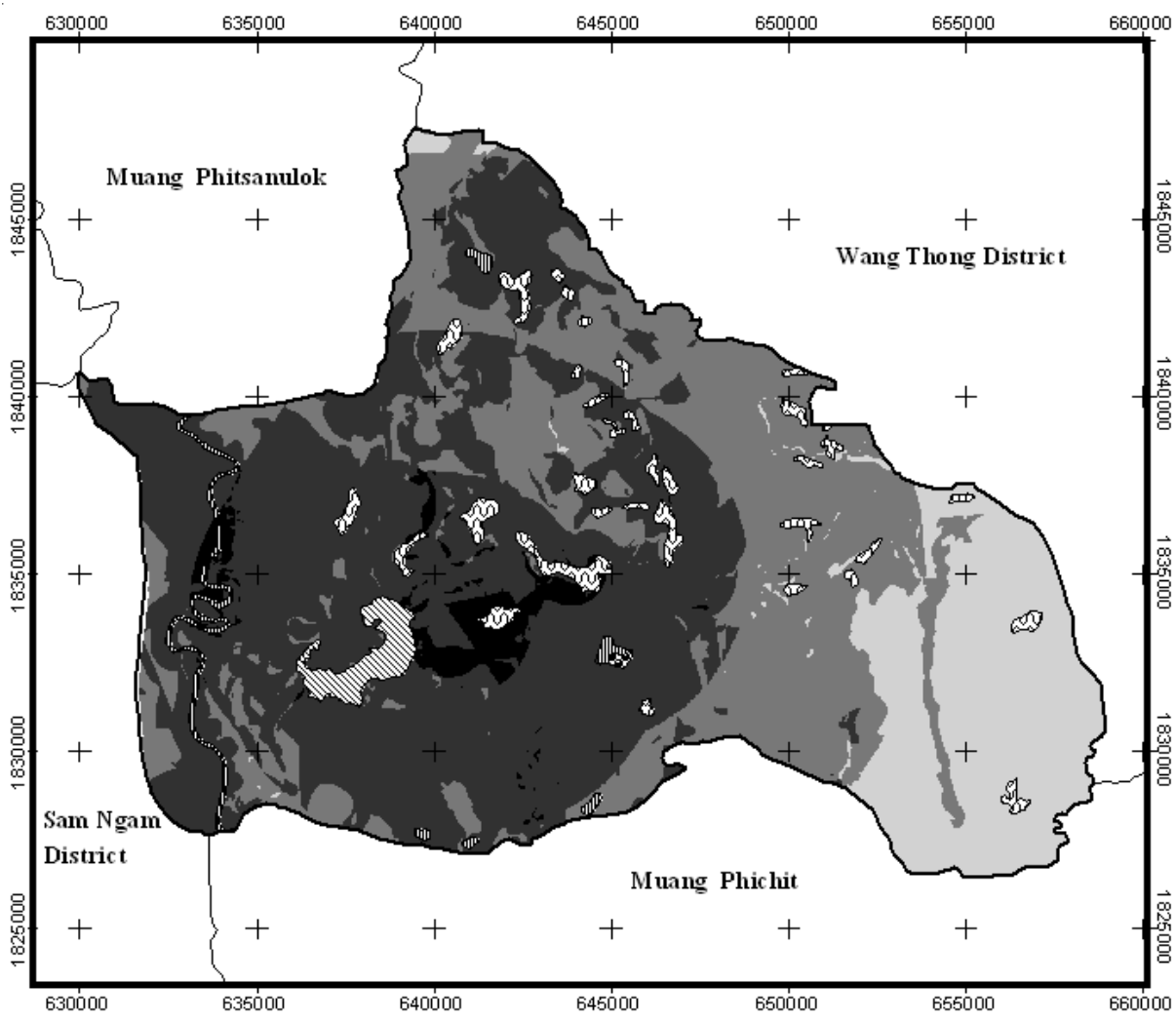

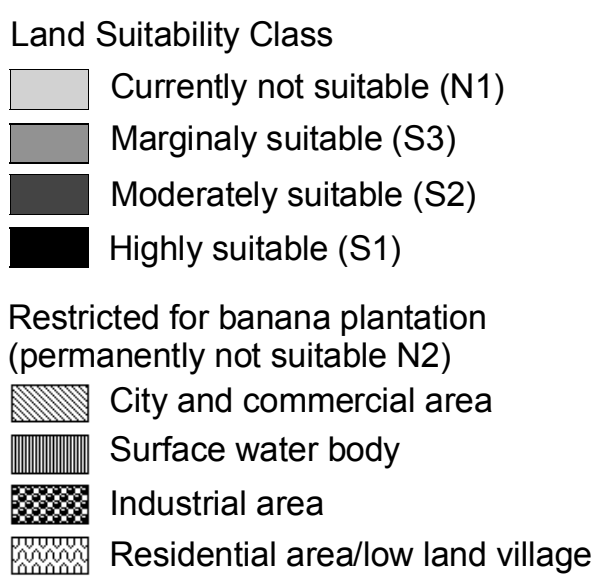

Fig. 3. Land suitability classification for Musa (ABB group) plantation

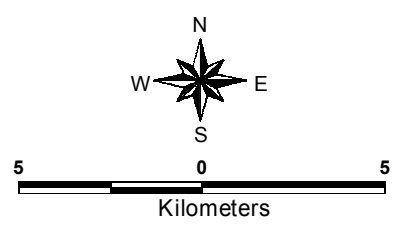


Table 6. Land suitability class for Musa (ABB group)

\begin{tabular}{lcc}
\hline Suitability Class & Area (ha.) & \% of Total Area \\
\hline Highly suitable (S1) & 928.08 & 2.66 \\
Moderately suitable (S2) & $16,111.96$ & 46.25 \\
Marginally suitable (S3) & $10,765.52$ & 30.90 \\
Currently not suitable (N1) & $5,400.60$ & 15.50 \\
Permanently not suitable (N2) & 1629.12 & 4.68 \\
Total & $34,866.24$ & 100.00 \\
\hline
\end{tabular}

sources are not necessarily unfavourable as well as some soil properties may be improved in terms of soil organic matter, soil drainage, or soil moisture.

Site selection of possible lands for new banana plantation: The matching of current land use with land suitability map is described here separately from economic and social analysis, which based on the functional relationship between the existing land use and the possibility of changing in land use for banana plantation. The matching of current land use type and land suitability classification can support or contribute information for site selection of new banana plantations. Although the highly and moderately suitable areas cover $48.91 \%$ of the study area, most of them have already been utilized for paddy fields and sugarcane cultivation, with about $62.99 \%$ and $74.65 \%$ of the area of highly suitable and moderately classes, respectively. These utilized lands may not be changed easily in the future. The alternative way of changing land use type for new banana plantation area might probably be in the area of mixed orchard and low land village/mixed orchard land use types. These types of land use cover 5,523.24 hectare $(15.84 \%$ of the total area) in all suitable classes (S1, S2, and S3). In addition, to finduout more possible land for banana plantation, some paddy fields such as an abandoned paddy field (about 425.24 hectare or $1.30 \%$ of the study area), which has also fallen in to all suitable classes, may be considered. Nevertheless, the options of changing the existing land into a new area for banana plantation must have the contemplation of socioeconomic and land improvement studies. Figure 4 (a) shows the possible areas for new banana plantation including areas of abandoned paddy field, mixed orchard and low land village/mixed orchard based to the land use in year 2002 .

Judging from the soil series within land suitability class, it is found that the areas of the highly suitable class (S1) is mainly covered by the soil series of Uttaradit series (Utt), Kamphaeng Saen series (Ks), and Ratchaburi series (Rb) with $69.55 \%$ of the area of highly suitable class. However, the Uttaradit and Ratchaburi soil series is more strongly suitable for paddy field than other agricultural use, while Kamphaeng Saen soil series has high capacity for any of agricultural use. Soil texture of Uttaradit and Ratchaburi soil series are clay loam and loamy clay with slightly acid topsoil (soil pH 5.5-6.5), as well as poor drainage with 3 to 5 months of flooding. The Fusarium wilt can be related with flooding problem. For the moderately suitable class (S2), the soil series distribution presents almost the same characteristics as highly suitable class. According to the soil characteristic (Land Development Department, 1998), most of the soil series in the study site were preferable for paddy fields except for That Phanom and Kamphaeng Saen soil series, which are very deep and well drained as well with less limitations for cultivation. Perusing the Chiang Rai soil series, the largest area among other soil series, it is the main area of the currently not suitable class (N1) with $71.56 \%$ of total currently-not-suitable- area. Chiang Rai soil series is classified into Plinthic Paleaquults, clayey, kalonitic (Land Development Department, 1998), where texture is silt clay loam and clay for topsoil and lower soil, respectively. This soil series has low suitability for perennial and horticulture crops because of long period of flooding, poor drainage, as well as low fertility of soil. However, crossing the soil series data with each class of land suitability for banana plantation depends on the important weight of combining five environmental factors. The above description of soil series concerned on land suitability class may not precisely mean some soil series are not suitable for banana plantation. For example, That Phanom soil series has great soil characteristic for horticulture crops, but located little bit distant from the household factory and fallen in the moderately suitable class of climatic factor, therefore, it is mostly assessed into moderately suitable class.

To determine the possible land for new banana plantation relating to integrated information of soil series data and land suitability class, the areas of any suitable class with good soil characteristic for banana plantation must be the first priority. The area of moderate and high suitability classes with any soil series under land improvement can be considered as the next priority. The two kinds of selected priority for new area of banana plantation are defined as $\mathrm{P} 1$ and $\mathrm{P} 2$, respectively. Table 7 shows the possible area of new banana plantation relating to $\mathrm{P} 1$ and $\mathrm{P} 2$ levels of priority. The area of P1 level consists of five soil series and covers 4,819.24 hectare ( $13.82 \%$ of the study area), that may be selected into the new area of banana plantation with low activity of land improvement. The P2 level consists of eighteen soil series, and covers 14,929.76 hectare or $42.82 \%$ of the study area, which has a lower soil productivity land than $\mathrm{P} 1$ level, but has moderately to highly suitability of current environmental condition for banana plantation. The $\mathrm{P} 2$ level require specific kinds of land improvement based on their requirements and limitations of soil series. However after land improvement and development, the lands in P2 level will have a higher potential suitability. Regarding to the study site exhibited slope gradient less than $2 \%$ in low land area, it was considered that this did not present any limitation to topography, therefore the topography aspect were not included in recommended soil improvements. All soil series in P2 level has similar limitations for banana plantations with low fertility, acidic soil, poor drainage, and long period of flooding. There is a 19,749.00 hectare or 56.64 $\%$ of the study area by selecting from the area of P1 and P2 levels, which can probably be conversed into new area of banana plantation (Fig. 4 (b)).

The process in defining a higher possibility of new banana plantation, it is suggested to use integrated information among land suitability assessment, current land uses type, and soil characteristics. The combination of soil properties and existing land use in year 2002 regarding the land suitability assessment has created the final site selection of new banana plantation. The result consists of four types of possible land with different land use and soil improvements. Abandoned paddy field, mixed orchard, and mixed orchard within low land village areas were chosen to combine with the selected soil series in P1 and P2 priorities. The total area of possible land for banana plantation is about $4,550.76$ hectare or $13.05 \%$ of the study. It is evident that only small area has the highest suitability in performing the new banana plantation (Table 8). 


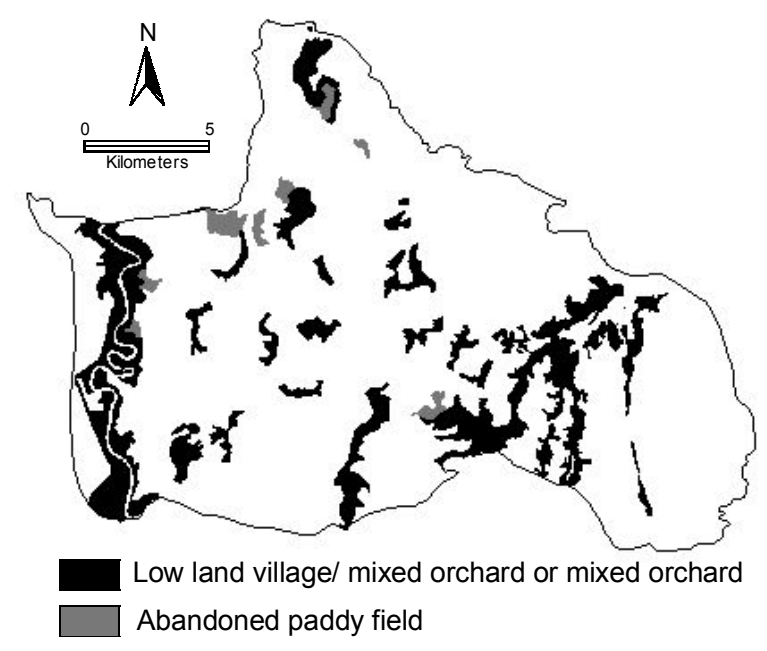

Fig. 4(a). The possible area for new banana plantation based on land use type

According to the soil characteristics, land in type I can be considered as the most preferable land with still unused area as well as without limitation of banana plantation because the lands with low improvements can reduce cost and agricultural input. For the land in type II, there is traditional land use pattern in Thailand to cultivate mixed horticulture crops within or nearby the village area, thus this type is also preferable to be changed into banana plantation, even though comparison of the benefit between crops is essential. Additionally, the lands in type II located in the southeast of the study site may have a water deficiency problem

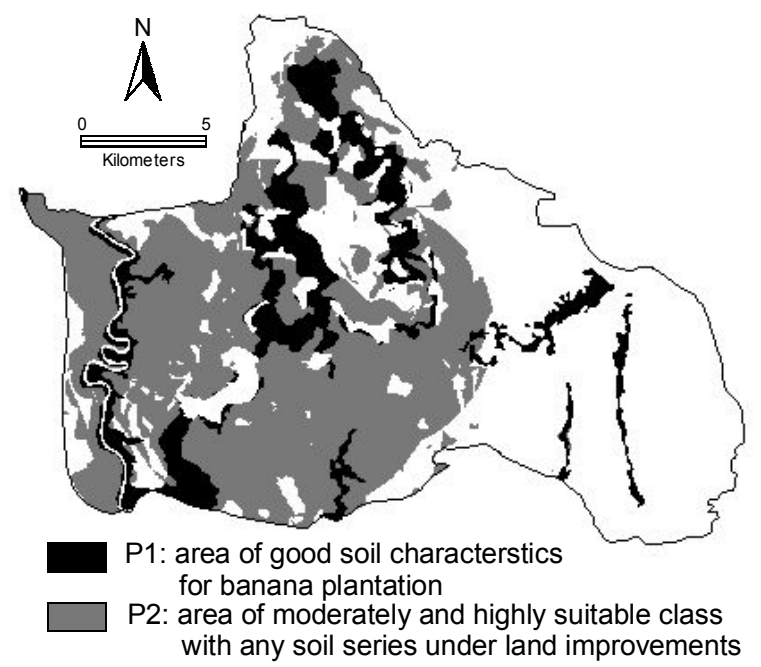

Fig.4(b). The possible area for new banana plantation based on soil series characteristic

(Fig. 5). If the banana plantation will really be considered, it is, therefore, necessary to extend the irrigation system. Lands along the Nan River, located at the west of the study site, cover some types of possible area for banana plantation i.e. Type II, III, and IV. These lands have high environmental suitability in soil properties and water use for cultivation, while they are marginally suitable in climatic and marketing factors. Lands in type III and type IV are depending on the opinion of landowners. These last two types of land need some activities of land improvement regarding to the limitation of soil series (Table 7). In addition to install a

Table 7. The possible area for new banana plantation based on soil series

\begin{tabular}{|c|c|c|c|c|c|c|c|c|c|}
\hline \multirow[t]{2}{*}{ Soil series } & \multirow[t]{2}{*}{ Soil series name } & \multirow[t]{2}{*}{ Area(ha) } & \multirow[t]{2}{*}{ P1 } & \multirow[t]{2}{*}{ P2 } & \multicolumn{4}{|c|}{ Limitation } & \multirow{2}{*}{$\begin{array}{l}\text { Land improvement } \\
\text { for banana } \\
\text { plantation }\end{array}$} \\
\hline & & & & & $\begin{array}{l}\text { Acidic } \\
\text { soil (pH) }\end{array}$ & $\begin{array}{l}\text { low } \\
\text { fertility }\end{array}$ & $\begin{array}{l}\text { poor } \\
\text { drainage }\end{array}$ & $\begin{array}{l}\text { Flooding } \\
\text { (Month) }\end{array}$ & \\
\hline 2 & That Phanom series: $\mathrm{Tp}$ & 432.88 & & $\sqrt{ }$ & & & & & No limitation \\
\hline 5 & Ratchaburi series : Rb & $2,395.04$ & & $\sqrt{ }$ & & & $\sqrt{ }$ & $4-5$ & $\mathrm{~T}, \mathrm{D}$ \\
\hline 6 & Saraburi series : Sb & 499.32 & & $\sqrt{ }$ & $5.0-7.0$ & & $\sqrt{ }$ & $4-5$ & L, T, D \\
\hline 7 & Singburi series : Sin & 178.04 & & $\sqrt{ }$ & & & $\sqrt{ }$ & $4-5$ & L, T, D \\
\hline 8 & Phimai series : Pm & 914.60 & & $\sqrt{ }$ & & & $\sqrt{ }$ & $4-5$ & L, T, D \\
\hline 9 & Chumseang series : Cs & 1.88 & & $\sqrt{ }$ & $4.5-5.0$ & & $\sqrt{ }$ & $4-6$ & $L, F, T, D$ \\
\hline 11 & Ratchaburi and Phimai soil & 98.32 & & $\sqrt{ }$ & $5.0-7.0$ & & $\sqrt{ }$ & $4-5$ & $\mathrm{~L}, \mathrm{~T}, \mathrm{D}$ \\
\hline 15 & Hang Dong series : Hd & 183.72 & & $\sqrt{ }$ & & & $\sqrt{ }$ & $4-5$ & $\mathrm{~T}, \mathrm{D}$ \\
\hline 16 & Mae Sai series : Ms & 185.92 & & $\sqrt{ }$ & & & $\sqrt{ }$ & $3-5$ & $L, F, T, D$ \\
\hline 19 & Chiang Rai series : $\mathrm{Cr}$ & 379.24 & & $\sqrt{ }$ & $4.5-5.5$ & $\sqrt{ }$ & $\sqrt{ }$ & $3-5$ & $L, F, T, D$ \\
\hline 20 & Chiang Rai over washed $p$ & 379.24 & & $\sqrt{ }$ & $4.5-5.5$ & $\sqrt{ }$ & $\sqrt{ }$ & $3-5$ & $L, F, T, D$ \\
\hline 25 & Phan series : Ph & 52.20 & & $\sqrt{ }$ & & & $\sqrt{ }$ & $4-5$ & $\mathrm{~T}, \mathrm{D}$ \\
\hline 27 & Uttaradit series : Utt & 4984.60 & & $\sqrt{ }$ & & & $\sqrt{ }$ & $3-4$ & T, D \\
\hline 30 & Uttaradit and Nan soils & 63.16 & & $\sqrt{ }$ & & & $\sqrt{ }$ & 3-4 & T, D \\
\hline 31 & Uttaradit/That Phanom Association & $1,265.96$ & & $\sqrt{ }$ & & & $\sqrt{ }$ & 3-4 & T, D \\
\hline 33 & Nan series : $\mathrm{Na}$ & $1,257.88$ & & $\sqrt{ }$ & & & $\sqrt{ }$ & 3-5 & T, D \\
\hline 34 & Nakon Pathom series : Np & $1,625.52$ & & $\sqrt{ }$ & & & $\sqrt{ }$ & 3-4 & $\mathrm{T}, \mathrm{D}$ \\
\hline 41 & Kamphaeng Saen series : Ks & $3,458.32$ & $\sqrt{ }$ & & & & & & No limitation \\
\hline 43 & Kamphaeng Saen moderatel & 97.40 & $\sqrt{ }$ & & & & & & No limitation \\
\hline 44 & Kamphaeng Saen and Tha M & 148.52 & $\sqrt{ }$ & & & & & & No limitation \\
\hline 53 & That Phanom and Kamphaeng Saen & 682.12 & $\sqrt{ }$ & & & & & & No limitation \\
\hline 121 & Alluvial Complex : AC & 457.60 & & $\sqrt{ }$ & & & & & Data not available \\
\hline \multirow[t]{2}{*}{123} & Alluvial soils & 7.52 & & $\sqrt{ }$ & & & & & Data not available \\
\hline & Total & $19,749.00$ & & & & & & & \\
\hline
\end{tabular}

L-liming; F-fertilizing; T-terracing; D-drainage system 
Table 8. The possible area for new banana plantation considering soil properties and existing land use in year 2002

\begin{tabular}{lcl}
\hline Type of possible area & Area (ha) & Description \\
\hline II & 160.20 & Area of abandoned paddy field without land improvement \\
III & $2,280.16$ & Area of mixed orchard and mixed orchard within low land village without land improvement \\
IV & 279.60 & Area of abandoned paddy field with land improvements \\
Total & $1,830.80$ & Area of mixed orchard / low land village with land improvements \\
\hline
\end{tabular}

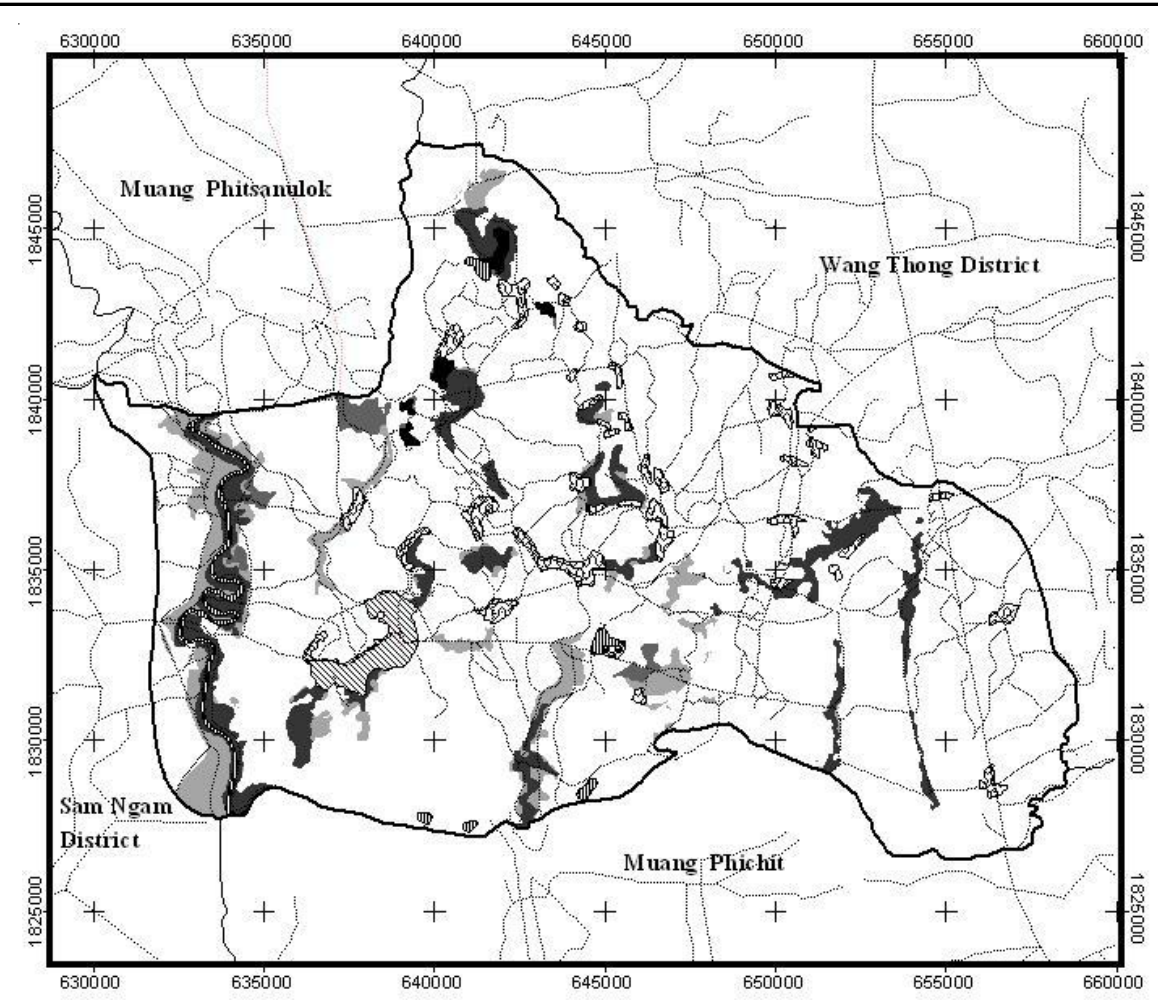

\section{Legend \\ Road network}

The possible area of new banana plantation considering soil properties and existing land use in year 2002

Type I: abandoned paddy field without land improvement

Type II: mixed orchard/ low land village without land improvemnt

Type III: abandoned paddy field with land improvement

Type IV: mixed orchard/ low land village with land improvement

Restricted for banana plantation

(permanently not suitable N2)
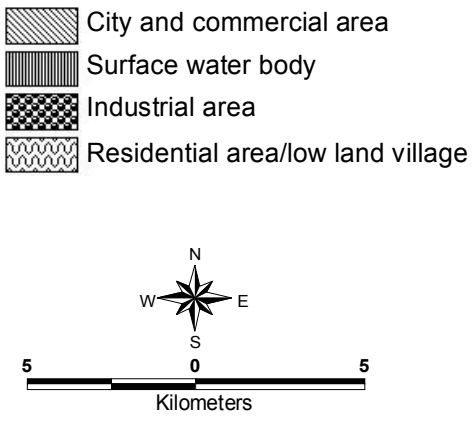

Fig. 5. The possible area for new banana plantation considering soil properties and existing land use in year 2002

higher environmental suitability of land, these areas require a massive capital investment in roads, drainage and irrigation, and packing facilities. Banana Link (2002) reported that intensive banana monoculture in Ecuador and Colombia results in very high yields about 50 to 80 ton per hectare compared with 15 to 25 ton per hectare in the Windward Islands. Based on the result of possible land for new banana plantation, if it is entirely changed into banana plantation, it is sufficient to supply raw banana material to the market as well as can fulfill the demand on dried banana product in the study area.

Acknowledgments: The authors express their acknowledgements to the National Science and Technology Development Agency (NSTDA) for finance granted for the realization of this work, included in the project approved under the code CO-B-06-2C26-405. The authors also want to thank the Agricultural \& Environmental Integration for Research and Development Unit, Naresuan University for their great support during the study.

\section{References}

Asian Institute of Technology, 2001. Agricultural Warning System Project. Ministry of Agriculture and Cooperatives. Bangkok. 626 pp.

Banana Link, 2002. Regions supplying the banana trade. Data on the Internet, [Online]. Available at www.bananalink.org.uk
Griffiths, F.J. 1994. Handbook of Agricultural Meteorology. Oxford University Press, Inc, New York Oxford, 320 pp.

Hackett, C. and J. Carolane, 1982. Edible Horticulture Crops : Part I Introduction and crop profiles (Section 1-6). $177 \mathrm{pp}$.

International Network for the Improvement of Banana and Plantain (INIBAP), 2001. Networking Banana and Plantains. September 2001. [Online]. Available at $h t t p: / / w w w . i n i b a p . o r g . ~ C e d e x$, France.

Land Development Department, 1998. Soil Resource Management Report for in the Lowland Area [CD-ROM]. Land Development Department. Ministry of Agriculture and Cooperatives. Bangkok. Thailand.

Land Development Department, 2002. Map of Land Use Types in Phitsanulok Province in Year 2002 [CD-ROM]. Land Development Department. Ministry of Agriculture and Cooperatives. Bangkok. Thailand.

Wattanachaiyingcharoen, D. and J. Boonyanuphap, 2003. Production Management of Musa (ABB group) "Kluai Nam Wa" for Export and Agro-industry Using GIS (Geographic Information System). Research report (In Thai, with English abstract). The National Science and Technology Development Agency (NSTDA). Bangkok. $114 \mathrm{pp}$.

Wattanachaiyingcharoen, D. 2002. The Development of Production and Management in Horticulture Products for Industry and Export in Lower Northern Thailand. Research Report (In Thai, with English abstract). Naresuan University. Phisanulok: 121-149. 